\title{
Modelization of the value chain for effective technology transfer within universities in Morocco
}

\author{
Omar ELYOUSSOUFI ATTOU ${ }^{1}$, Said EL GANICH ${ }^{2}$, Ilham TAOUAF ${ }^{3}$, Moha AROUCH ${ }^{4}$, Badia \\ OULHADJ ${ }^{5}$ \\ ${ }^{1}$ Engineering, Industrial Management \& Innovation Laboratory - Faculty of Sciences and Techniques of Settat- \\ Hassan 1st University, Morocco, om.elyoussoufi@gmail.com \\ ${ }^{2}$ Strategy and Management of Organizations Laboratory-National School of Business and Management- Hassan \\ 1st University of Settat, Morocco, elganich@yahoo.fr \\ ${ }^{3}$ Engineering, Industrial Management \& Innovation Laboratory - Faculty of Sciences and Techniques of Settat- \\ Hassan 1st University, Morocco, i.taouaf@uhp.ac.ma \\ ${ }^{4}$ Professor of higher education- Engineering, Industrial Management \& Innovation Laboratory - Faculty of \\ Sciences and Techniques of Settat Hassan 1st University, Morocco, moha.arouch@uhp.ac.ma \\ ${ }^{5}$ Professor of higher education- Strategy and Management of Organizations Laboratory-National School of \\ Business and Management- Hassan 1st University of Settat, Morocco, b.oulhaj@gmail.com
}

\begin{abstract}
The collaboration between universities and companies in Morocco has undergone remarkable development in recent years. It has been developed to different degrees ranging from continuous training to collaborative R\&D and technology transfer (TT) to the industrial sector. In order to make this collaboration a success, authorities and public universities have adopted several policies and programs that aim at, overall, the establishment of an efficient national system of technological innovation. Unfortunately, efforts made to date have not allowed universities to reach their full potential.

This paper will analyses the different policies and programs related to TT. The main objectives are to model the current process of $\mathrm{TT}$ in universities and to propose appropriate activities to promote value chain for the TT process.
\end{abstract}

Key words: Management of Technology and Innovation, technology transfer, University TTO, R\&D, Morocco.

\section{INTRODUCTION}

There has been a noticeable development in terms of the collaboration between universities and companies in Morocco over the past fifteen years. This collaboration has developed to varying degrees, depending on the level of trust between the two parties. In general, it has included training, expertise, engineering, Technology Transfer (TT) and collaborative R\&D.

This interaction between companies and universities is largely dependent on the changes taking place in both the business and university worlds in the country.
Indeed, economic systems increasingly rely on science, technology and innovation to improve their competitiveness. In fact, decision-makers are convinced of the crucial role that the promotion of R\&D can play in this regard [1].

As for universities, they are asked to provide part of their budget through their own resources. For example, Moroccan universities are governed by Law 01.00 which clearly stipulates that [2]: Law 01.00 (2000)

"Within the framework of the missions assigned to them by this Law, universities may provide services by agreement for a fee, create innovative business incubators, exploit patents and licences and market the products of their activities...".

In addition, the university's prerogatives and fields of action have gradually broadened to enable it, in addition to its training and research missions, to carry out a third mission devoted to the commercialization and the valorisation of research results, entrepreneurship and Technology Transfer towards the socio-economic fabric [3], [4].

Activities related to the exploitation of research results go beyond the traditional activities of creating and disseminating knowledge, including the publication of scientific articles. It is all about managing Intellectual Property (IP), from protection to licensing, creating start-ups and spin-offs, conducting collaborative $R \& D$ projects with economic partners and providing expertise for them [5].

These activities and mechanisms have become very widespread in recent years and are attracting increasing attention in universities and research centers [6]. 
In order to achieve the third mission, scientific literature has prescribed the establishment of autonomous units alongside the other traditional units that manage teaching and research. This type of unit has been named "Technology Transfer Office (TTO)" [1], [7], [8].

In recent years, several studies and research have focused on the commercialization of research results and more specifically on the missions of TTOs. An analysis of this literature reveals the following:

- TTO's activities and main functions have been extensively studied [7];

- Confirmation of the role of the TTO in licensing and patents [9], [10];

- The importance of the creation of university spin-offs and their performance [11], [12], [13];

- The importance of the creation of university spin-offs as a result of the commercialization of public research [14], [5];

- Much of the research in this area has focused on TTO activities related to the commercialization of university Intellectual Property at several levels:

- Encouraging researchers to disclose their inventions and assessing their patentability, technological validity and commercialization potential [15], [16];

- The interface role that reduces the problem of asymmetric information between industry and academia [17] and reduces uncertainty about the profitability of new inventions [18].

- The organizational aspect of the TTO, which in most studies takes the form of a centralized and hierarchical structure, integrated at the central level of the university. However, some studies have argued that TTOs can take different organizational forms.

- The three TTO archetypes identified by Markman and al (2005) [19], which vary according to the degree of autonomy granted to TTOs (traditional university structure, non-profit foundation and a for-profit subsidiary company);

- The four organizational forms proposed by Bercovitz and al (2001) [20], the unitary structure (U-form), the multi-divisional structure (M-form), the holding company (H-form) and the matrix structure (MX-form).

- The example of decentralized TTO studied by Debackere and Veugelers (2005) [14].

In summary, the literature review highlights the scarcity of studies that address the roles of TTOs during the early stages of the commercialization process of research results and technology transfer. Thus, this work will place special emphasis on the phases upstream of the proposed TT process for Moroccan universities, while detailing the missions and roles of the TTOs, which we will now call the Technology

\section{Transfer University Office (TTUO).}

In Morocco, "Interfaces Université-Entreprise" (the Moroccan version of TTOs) have been set up since 1998 in most universities and research centers in Morocco. The main objective was to carry out the third mission through the management of collaboration and partnership with the socio-economic world [21], [22].

As for the promotion of the valorisation of research results through the creation of innovative start-ups, "university technology incubators" have been set up and supported since 2002 through a National Incubation Network called "RMIE" [23], [24], [25].

So, in this work we will:

- Analyse the policies, the programs, the practices and the achievements, within Moroccan universities, related to TT activities towards the industrial fabric;

- Analyse and model the current process of Technology Transfer in Moroccan universities;

- Propose a value chain, more appropriate for Moroccan universities, of technology transfer process while detailing the characteristics and the main functions of TTUO structures in Moroccan universities

- Propose, for Moroccan universities, a set of measures to be adopted in order to activate and to professionalize the activities of TTUOs.

- The objective, in a second step, is to propose an efficient institutional "TT policy" based on a complete reference framework for the implementation of TTUOs. This reference framework should consolidate the implementation conditions, attributions and activities, components and the organizational aspect.

\section{METHODOLOGY}

In order to model the current TT process, in Moroccan universities, and then propose a more appropriate value chain for the TT process and finally propose, for Moroccan universities, a complete reference framework for the implementation of TTUO, we have proceeded as follows:

1) Analysis of reports produced by the various stakeholders involved in the scientific research and innovation system in Morocco [21], [24], [26], [27], [28].

2) Analysis of results and achievements related to innovation promotion programs as part of the Strategy: "Morocco Innovation" launched by the two Moroccan ministries in charge of scientific research and industry from 2011 to 2015.

3) Analysis of the results of the national programs promoting innovative activities within companies, with a special focus on certain "success stories" companies benefiting from innovation support mechanisms, promoted since 2003. 
4) Conducting direct interviews with the managers of eight (8) clusters (list in appendix 1) among the 11 clusters labelled by the Moroccan Ministry of Industry. Industrial clusters in Morocco are promoted as an enabling ecosystems to the emergence of collaborative innovation projects between companies and research laboratories and also as sources of innovative start-up projects;

5) Analysis of the TT process and IP management in the 8 of the 12 Moroccan universities most concerned by these activities:

- Choice of public universities chosen on the basis of the existence of a TT structures and especially the achievements in terms of patent applications submitted to the Moroccan Office of Industrial and Commercial Property (OMPIC) [26] (List of selected universities in Appendix 2).

- Collecting documents and reports related to TT and IP activities (activities reports, websites, OMPIC activities reports from 2009 to 2016, etc.);

- Conducting direct interviews with current and former officials in charge of the:

- University-Business Interfaces (List in appendix 3);

- Technology and Innovation Support Centers in Moroccan universities (TISC);

- University incubators (List of the incubators in appendix 4).

6) Compiled information on the field, relative to the national program of establishing pilot Innovation Parks (List of the 4 pilot Innovation Parks in appendix 5):

- Conducting direct interviews with project managers in universities;

- Conducting direct interviews with officials at the national level;

- Analysing Innovation promotion schemes already in place in the 4 pilot innovation Parks;

- Sources of funding and regulatory framework covering the activities of the 4 pilot innovation Parks.

7) Identification of the current situation and constraints affecting the promotion of innovation in Morocco. Interviews were held with officials representing the national institutions involved in the national research and innovation system.

- Heads of universities and institutes benefiting from various programs and support mechanisms;

- heads (Top management) of the guidance, coordination, planning and steering bodies.

\section{TECHNOLOGY TRANSFER ACTIVITIES IN THE MOROCCAN UNIVERSITIES}

\subsection{Analysis of the results of innovation and TT support programs in Moroccan universities}

The year 2000 marked the beginning of the process of establishing a national innovation system in Morocco; thus, several strategies and programs to encourage innovation have been promoted by the Moroccan public authorities [29].

In what follows, we will present the analysis of the results of innovation support programs and more particularly the activities related to TT in Moroccan universities.

These programs and mechanisms can be divided into two main categories; Supporting Infrastructures and Funding Mechanisms [29].

\section{A.Supporting Infrastructures}

- The National Program of University-Business Interface Structures [21], [22].

- The Moroccan Network for Incubation and spinoffs (RMIE) [23], [24], [25].

- The National Program of establishing pilot Innovation Parks in 4 Moroccan universities (Fez, Marrakech, Rabat and Settat) [30].

- The national Support Program for the Institutionalization of IP protection mechanisms in universities and Research Institutions (TISC Network); The number of patent applications by universities increased from 11 in 2009 to 155 in 2016 (which represents $65.4 \%$ compared to the 237 Moroccan patents filed in 2016) [21], [26], [31].

- The National Program supporting the establishment of Moroccan clusters [27], [32].

- The National Program supporting Industrial Technical Centers (CTI) [33].

\section{B.Funding mechanisms}

- Call for projects, launched in 2013, covering the priority areas of scientific research and technological development, in particular category C. This category concerns projects which aim to develop market-oriented products in advanced technologies and improve the competitiveness of companies [25], [34].

- Call for projects, launched in 2014, relating to R\&D in the field of phosphates in partnership with the "Office Chérifien des Phosphates" (OCP) [25].

- INNOV'ACT Program (2005-2011) [28], [35].

- Technology Diffusion Network -RDT- (2003-2011) [28].

- Innovation financing mechanisms: via the Innovation Support Fund $(\mathrm{FSI}=380 \mathrm{MDH})$. They are dedicated to supporting innovation projects by companies operating in the industrial sector. Between 2011 and 2014 Seven (7) editions of calls for projects were launched, 352 projects submitted, 74 projects selected, 60 projects supported [27]:

- INTILAK Program: Support start-ups. 49 selected projects out of 226 filed.

- TATWIR Program: support innovation and R\&D 
projects carried by companies, in the development phase. 16 selected projects out of 83 filed.

- PTR Program: support technological diagnostics or services as part of an innovation approach. 9 Projects selected out of 43 filed.

\section{The Analysis of the results and identification of constraints that hinder the achievement of the expected objectives of TT activities in Moroccan universities}

The analysis of the reports, carried out by the various stakeholders involved in the scientific research and innovation system in Morocco, has enabled us to highlight a set of general observations on the results achieved through the different mechanisms and programs aimed at supporting innovation and TT in universities, namely:

- Most of the universities and research centers have a university incubator, a university-industry interface structure and a Technology and Innovation Support Center (TISC) integrated with or independent from the interface structure.

- All previous structures are University internal units and the level of their activities varies between:

- Raising awareness and organizing meetings and debates with economic partners.

- Intellectual property management.

- Management of contracts with economic partners.

- Technological Support for Startup project promoters.

- Commercial Support for Startup project promoters.

- The results remain limited in terms of development of Startups and Spin-off, research projects in cooperation with economic partners or technological services provided by universities.

On the other hand, the analysis of the results related to the implementation of the National Program of University-Enterprise Interfaces (1998-2011) and the Moroccan Network for Incubation and spinoffs (2002-2017) as the two programs [36], [37], [38] supporting R\&D valorisation structures and TT has enabled us, first, to note the weak achievements and then to identify the main factors and constraints that:

- Hinder the achievement of the expected objectives of TT activities in universities carried out by these structures.

- Explain the low mobilization of researchers for industry and the low participation rate of universities as technological services providers in some networks and programs.

These factors and constraints can be summarized and categorized into 5 main categories as follows:

\section{"Paradigm" category.}

Constraints related to the belief and hypothesis system that form the way of thinking of actors within the university about TT activities that allows them to formally define the objectives and understand their roles as well as the roles and missions of TTUO:

1. After a certain period of time since their establishment, the majority of the structures are converting towards company placements and insertion of the graduates instead of taking care of the valorization and TT missions.

2. University incubators support start-up projects only up to the business plan development phase and rarely intervene downstream during the fundraising phase;

3. Weak culture of patents and IP within the Moroccan university;

4. Researchers prefer to promote their work through scientific publications.

5. Difficulty in orienting research towards the needs of companies. Such an orientation requires a strategic vision and formal recognition of the university's third mission.

\section{"Policy and Governance" category.}

6. Lack of institutionalization of valorization and TT structures (interface, incubator, innovation city...):

The lack of a proper mode of governance and a legal status, characterized by administrative and financial autonomy, represents the greatest handicap and strongly affects the success and sustainability of all the actions undertaken in this context. For example, the EU interfaces during the pilot phase (1998-2004) and the first phase of sustainability (2004-2007) have been able to achieve significant success stories, in particular due to support from the national program coordinated by the Ministry in charge of scientific research and also due to the resources mobilized as part of the international partnership (Tempus SILA Program). However, despite continued efforts to ensure the sustainability of these structures, the lack of adequate status has undermined their institutionalization and has had a significant impact on their achievements [39].

7. Until the establishment of a legal status that will guarantee autonomy and efficiency, these structures are not even visible in the organizational charts of universities, which makes it difficult to acquire adequate equipment or expertise for projects.

8. The complexity and slowness of administrative and financial management:

Issues related to administrative and financial management procedures in Moroccan universities are considered among the most important obstacles. Indeed, regardless of the source of financial resources (public funds, own funds, subsidies, private revenues, international cooperation funds, etc.), their management is subject to the same rules for the expenditure of public subsidies, which has a heavy impact on research results and, more seriously, on commercialization, innovation 
and TT activities. For example, to date, no university has succeeded in applying Article 7 of the Act 01.00, which allows it to create or take stakes in companies that result from the valorization of scientific research [40], [41].

9. Lack of a professional structure capable of commercializing university patents.

10. Weakness of the institutional, industrial and financial network of TTUOs.

11. Lack of structured communication with the socio-economic world.

12. Lack of a system for evaluating the TT activity.

\section{"Legal framework and national legislation" Category}

13. Lack of an adequate legal framework to regulate the activities of these structures.

14. Lack of a compensation and motivation mechanism for teacher-researchers, administrative and technical staff.

15. Non-recognition of the functions and efforts made at the level of the valorization structure in the career progression of the HR involved.

16. Lack of legal instruments to mobilize university researchers who carry out commercialization projects.

\section{"Resources" Category}

This category is divided into five types of resources; human resources, material resources, financial resources, and project flow and market.

Human Resources, Skills and Expertise:

17. General lack of human resources.

18. HR turnover is strongly linked to the change of university presidents; even more so, a total replacement of teams is done without any capitalization. Indeed, the new teams systematically have difficulties acquiring the information, data, reports and previous achievements of their own structures.

19. The resource person(s) working in the structure are only partially dedicated to it, since they perform other administrative and/or teaching tasks at the university.

20. Absence or low qualifications of the resource persons in the fields of TT and IP.

21. Difficulties related to the scarcity of experts (technical, legal and economic skills) capable of ensuring the economic valuation of IP and decision-making on the usefulness of legal protection.

\section{Material resources:}

22. Difficulties in making prototypes resulting from the lack of financial and technical support for researchers during the "proof-of-concept" stage and prototype production.

Financial resources:

23. Low budgets allocated to TT activities including those related to IP protection and management.

24. Difficulties in motivating researchers to pursue IP protection.
Flow of research projects to be valorized (raw material)

25. Predominance of basic research at the Moroccan university.

26. Predominance of the "teaching" vocation among Moroccan research professors limiting the load dedicated to research and the production of knowledge.

The Market:

27. The market's ability to absorb the technologies proposed by the university is a very limiting constraint on TT activities in universities. Indeed, the low demand for university expertise and technology and collaborative $R \& D$ projects with universities can be explained by the nature of the national economic fabric, which is mainly made up of small and medium-sized enterprises that rarely take an interest in innovation and R\&D as tools for developing their activities.

\section{"External constraints" Category}

The achievement of TTUO objectives is strongly conditioned by external constraints that are the responsibility of other actors in what may be called the national innovation ecosystem. Indeed, it is necessary to work on the establishment of an effective national ecosystem to ensure the emergence of innovation and TT activities at the national level. This issue could be studied in depth in future work. External constraints include, among others:

28. The weakness of adequate financing mechanisms to support the creation of Startups (seed funds, business angels, etc.), to support innovation and TT from universities to Moroccan companies.

29. The low financial participation of the private sector in the R\&D national effort.

30. The Moroccan industrial fabric is characterized by the preference for the acquisition of turnkey technologies and licensed manufacturing instead of local development of advanced technologies.

31. Negative perception by industrials of the image of national scientific research.

\subsection{Characteristics of TTUO in Moroccan universities}

Direct interviews with current and former managers in charge of TTUO structures in Moroccan universities (University-Business Interfaces; Pilot Projects of Cities of Innovation; Technology Information Centers (TISCs) and University Incubators) helped us to determine the TT model, functions and process implemented by the aforementioned structures.

\section{A. Model of the TTUO structures currently adopted in Moroccan universities.}


The organizational aspect of TTUO currently adopted in Moroccan universities consists of a centralized and hierarchical structure, integrated at the central level of the university, this is the "traditional university structure" identified by Markman et al (2005) [19], among the three (3) archetypes of TTOs that vary according to the degree of autonomy assigned to TTO (traditional university structure, non-profit foundation and a for-profit subsidiary company).In fact, this is the "inside" model of TTUO, which takes the form of a department of the university that operates under the direct supervision of the university president.
The project currently being set up to set up pilot innovation cities in 4 Moroccan universities plans to adopt the "non-profit foundation" archetype, which is a model qualified as "participation": The TTO is an independent legal entity with which the university has strong links (the university is a member of the board of directors with, often, the status of president, a quality or leading voter...).

In the table below, we present a comparative analysis of the main characteristics of the TTUO currently adopted in Moroccan universities with the three archetypes of TTO:

Table 1: Comparison of the main characteristics of TTUO in Moroccan universities with the three archetypes of TTO.

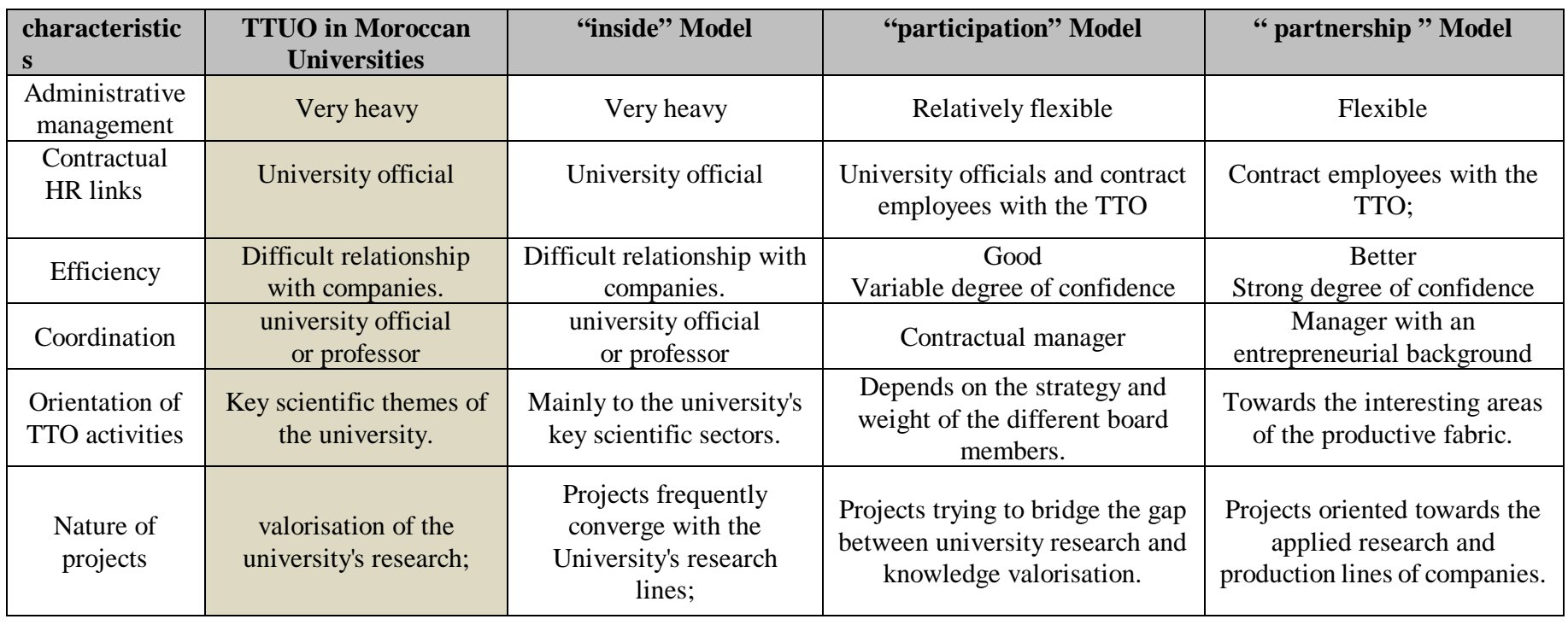

\section{B. The Main functions of the TTUO structures currently in place in Moroccan universities:}

In the table below, we present the level of execution of the main functions of Moroccan TTUO structures, which are identified in the literature [7], [9], [10], [11], [12], [13].

The level of execution of each activity was measured on a scale of 1 to 5 , according to the average perception of the different stakeholders in the TT process in Moroccan universities (TTUO managers, university managers, institutional managers, researchers, economic partners, etc...).

Table 2: Level of execution of the main functions of TTUO structures in Moroccan universities.

\begin{tabular}{|c|l|l|l|l|l|l|}
\hline \multirow{2}{*}{$\mathbf{N}^{\circ}$} & \multicolumn{3}{|c|}{$\begin{array}{l}\text { Main fonctions of the TTUO } \\
\text { structures }\end{array}$} & \multicolumn{4}{|c|}{$\begin{array}{c}\text { Level of } \\
\text { execution }\end{array}$} \\
\hline $\mathbf{1}$ & $\begin{array}{l}\text { Awareness-raising and capacity } \\
\text { building }\end{array}$ & & & & & $\sqrt{ }$ \\
\hline $\mathbf{2}$ & $\begin{array}{l}\text { Contest of ideas to evaluate the } \\
\text { proposals of young students or } \\
\text { graduates.; }\end{array}$ & & & & & $\sqrt{ }$ \\
\hline
\end{tabular}

\begin{tabular}{|c|c|c|c|}
\hline 3 & Promoting and supporting spin-offs; & $\sqrt{ }$ & \\
\hline 4 & Management of incubation activities & $\sqrt{ }$ & \\
\hline 5 & $\begin{array}{l}\text { Dissemination of IP mechanisms and } \\
\text { patent preparation; }\end{array}$ & & $\sqrt{ }$ \\
\hline 6 & $\begin{array}{ll}\text { Determining } & \text { the conditions for } \\
\text { establishing } \\
\text { contracts; }\end{array}$ & $\mathrm{N}$ & \\
\hline 7 & Technology Service Delivery Centre; & $\sqrt{1}$ & \\
\hline 8 & $\begin{array}{l}\text { Collaboration project between } \\
\text { research units and businesses. }\end{array}$ & $\sqrt{1}$ & \\
\hline
\end{tabular}

\section{MODELIZATION OF THE VALUE CHAIN OF THE TT IN MOROCCAN UNIVERSITIES.}

The main TT activities in Moroccan universities consist of:

- Valorization of scientific research's results and transforming it into a commercial offer in the form of a technology, product or service (technical expertise) that can be used by a partner or group of economic partners.

- Supporting university laboratories and economic partners in the contractualization process in order to set up collaborative research contracts;

- Supporting Startup and spin-off project promoters; 
- IP management and patent licensing of inventions.

The ultimate goal is to disseminate knowledge and technologies in the socio-economic fabric and to achieve the university's third mission by providing the market with new products, services and ideas and creating high value-added jobs.

In order to achieve this mission and to succeed in increasing the social and economic impact of national scientific research, particularly publicly funded research, universities must master the TT process. They can achieve this objective through:

- Exploitation of all diffusion and transfer mechanisms to valorize the technological offer such as licensing of patents, start-ups and spin-offs and R\&D cooperation agreements.

- Collaboration with all potential partners (such as start-ups, existing companies, investors, SMEs, NGOs, innovation and valorization promotion agencies and governments).

Table 3: Phase $\mathrm{N}^{\circ} 1$ (Maturation and orientation of the TT process in Moroccan universities) TTUO activities.

\subsection{Phases and stages of the TT process in Moroccan universities. \\ Technology Transfer in the academic context is a complex and repetitive process that includes overlapping phases and stages. In the following, we will identify these phases and stages before proposing a modelization of this process as a "value chain" [42], [15], [43].} significant loss between the inputs (research projects and allocated resources) and the outputs (technological services, licenses, start-ups, spin-offs, joint ventures, etc.).

- Adopting a set of measures to activate and professionalize

\section{Phase $\mathrm{N}^{\circ} 1$ : Maturation and orientation phase}

Focus generally on the generation of project flows and ensure a high and intensive level of activities related to technological production and the valorization of research's results at multiple levels:
- Awareness-raising and dissemination of the innovation and technology transfer culture

- Promotion of innovation and R \& D;

- Fostering projects;

- high quality education and training

- Identification and communication around research areas and new ideas for technologies, products or services with a potential commercial advantage.

- Technology watch ;

- Carry out technology foresight to identify emerging technologies.

- Supporting (technical \&Finance) researchers during the proof-of-concept or prototype production stages.

- Monitoring the needs of the local, regional, national and international economic environment.

- Developing partnership and cooperation with the private and industrial sectors.

- Stimulate and reward researchers for their commitment and contribution to innovation and TT by providing financial incentives:

$\checkmark$ Direct financial rewards and benefit sharing;

$\checkmark$ Academic promotion

$\checkmark$ Recognition (Awards, communication on "success stories")

This is a crucial phase that makes it possible to act upstream by directing research results more reliably towards the desired industrial applications, by providing support and monitoring of the following aspects:
Technical aspect: By verifying the validity of the feasibility step, the Proof of Concept step, the Prototyping step, and the manufacturing model Production step (depending on the Commercialization Method selected and adopted).

Intellectual Property aspect:

Legal aspect: linked to contractual agreements with industrial and private partners and the extent to which national standards and laws are respected.

Marketing and commercial aspect: concerning the definition of the commercial offer related to the proposed technology, the business model and the market research. 
Table 4: Phase $\mathrm{N}^{\circ} 2$ (Legal disclosure and legal protection of the invention)

\section{Phase $\mathbf{N}^{\circ}$ 2: legal Disclosure and protection of the invention or the technology}

This phase includes a set of stages as follows:

Stage $\quad \mathbf{N}^{\circ}$ 2.1: $\quad$ Disclosure of new Detailed description of the technology or the invention: (Includes two levels of technologies, products or services (according to the Standard-Disclosure Form):

In this form, several aspects about the invention must be detailed. These aspects may include:

information: confidential and non-confidential):

- Date of the invention/ invention

- Advantages of the technology/invention and potential areas of application and exploitation.

- Those who may be interested in exploiting this technology;

- Level of development and proof of concept.

information about the sources of funding that have been involved in technology/invention development or used in initial research and development;

The names of inventors and the degree of their contributions and the researchers who have been directly or indirectly involved in the development of the technology.

Laboratory notes, records, documents and diagrams enclosed as proof.

Information on publications and similar technologies

Stage $\mathbf{N}^{\circ}$ 2.2: Archives and IP Data - Data recording;

Management $\quad$ - Data archiving;

- Data confidentiality management.

Stage $\mathbf{N}^{\circ}$ 2.3: Assessing existing intellectual property and research the state of the art that may affect the freedom of R\&D activities.

Stage $\mathbf{N}^{\circ}$ 2.4: Making decisions about the usefulness of legal protection and the geographical scope of the protection required. The existing IP laws in Morocco should be respected.

\section{Stage $\mathbf{N}^{\circ}$ 2.5:}

Filing formally the patent application the university has to choose:

- Either to protect the IP using existing university resources (The need for technological and commercial expertise)

- Or to renounce the IP ownership for the benefit of the researcher (who shall uses his own resources to follow up the protection process)

Follow the different steps of the patent application process through:

- Direct supervision, by the relevant office of the university (advantages and disadvantages);

- Or to engage the services of appropriate experts with expertise in relevant fields (advantages and disadvantages).

Table $\mathbf{N}^{\circ}$ 5: Phase $\mathrm{N}^{\circ} 3$ (Technology Transfer and Commercialization)

\section{Phase $\mathrm{N}^{\circ} 3$ : Effective technology transfer and commercialization}

The university develop her own strategy to decide how the technology will be used based on available options and how to allocate commercialization responsibilities.

This strategy should take into account a combination of factors, the most significant of which are:

- Conflicts of interests concerning collaborative and contractual research activities.

- Protection of national interest (in the case of an operating licence transferred to a foreign economic partner;)

- protection of public interest (In the case of publicly funded $\mathrm{R} \& \mathrm{D})$

\section{1) Transfer of patent ownership (license transfer)}

2) Licensing: It may include many options such as a set of exclusive and non-exclusive licenses:

Conditions of the option and its advantages:

- The proposed technology is a progressive development of a technology or a product found in the market;

- Significant costs for further development and/or the production of the manufacturing model;

- A relatively simple and standardized option;

- Requires relatively minor funding from the university, mainly related to the legal protection costs.

\section{disadvantages of this option:}

- Provides limited incomes that are not related to the possibilities of the product commercial success;

- In the case of a licensing to a foreign economic partner: Miss potential future income opportunities from manufacturing and marketing and the steady growth associated with national investment in this technology;

3) Start-up creation

4) Academic spin-off creation

5) Setting up joint ventures with economic partners to share both risks and potential rewards

Conditions of the previous three options and their common advantages: 


\begin{tabular}{|l|l|}
\hline In general, the possible & - Contribution to regional and national economic growth; \\
commercialization options as part & - Development of a national economic fabric with high added value especially among small \\
of a TT strategy are: & and medium-sized enterprises; \\
& - Promotion of associated activities such as manufacturing and marketing; \\
& Disadvantages of those three options: \\
& - Require the mobilization of considerable human resources (HR) and it's difficult to justify \\
& in the context of increasing demands on HR for teaching and training functions; \\
& - Requires the inventor to make a temporarily or permanently conversion of his job \\
& functions; \\
& - Is not commensurate with the management practices and the prevailing culture at the \\
& university; \\
& - Is not sufficiently commensurate with the applicable laws and regulations. (civil service \\
& legislation, Organic Law setting out the regulations for teachers and researchers in higher \\
& education and scientific research, law governing the functioning of the university as a \\
& public institution); \\
& - very poor or even non-existent income during the first years of the company; \\
& - The legal requirement that the university's contribution should not be less than $20 \%$ of the \\
& start-up capital may be an obstacle.
\end{tabular}

\subsection{Proposed Value chain of the TT process for Moroccan universities}

The three major phases, mentioned above, are divided into smaller steps with results that must be validated before proceeding to the next step.

The above steps can be implemented either at the level of university research laboratories, or by specialized structures within the university, or by using national innovation structures or intermediaries or directly in collaboration with the economic partner.

Figure 1 below summarizes the different phases and stages of the value chain of the TT process in Moroccan universities, as well as the stakeholders involved along the process. This value chain is proposed on the basis of:

- The results and feedback on the experiences of TT activities in Moroccan universities over the last ten years;

- The model and experience of Technology Transfer Acceleration Companies in France [44].

- Some classic academic models in which the "value chain" of the TT process in the university is represented in a linear way that is characterized by a successive sequence of process steps as follows

- The process is triggered by an invention or discovery made by a researcher or a group of university researchers;

- Then, the researcher discloses the invention to the TTO;

- This is followed by the formal disclosure stage and the application for a patent by the TTO after examination and decision on the usefulness of legal protection.

- And finally the effective TT and commercialization.

However, these academic models are simplistic and rigid since they consider that the same process is appropriate for all cases. TT is a complex, repetitive and intertwined process that requires feedback between the steps and the three main phases.

In order to ensure the relevance of the choices of technologies to be developed and the promising industrial fields of application and with a view to achieving TT as soon as possible, we strongly recommend to work during the first phase, relating to maturation and orientation, in cooperation with one or more economic partners.

The graph below illustrates the value chain of the TT process that we propose for Moroccan universities. 


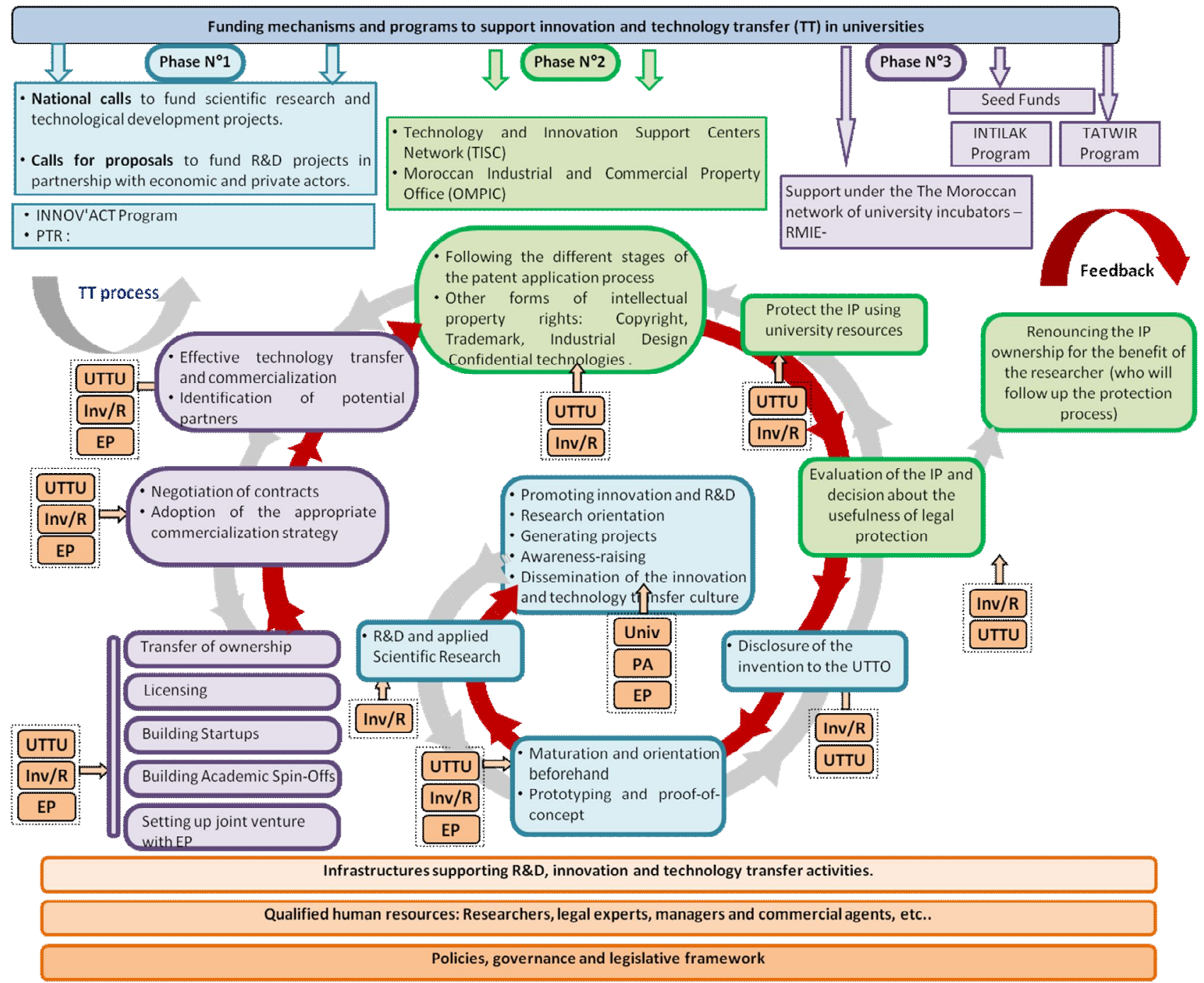

Figure 1: Phases, stages and stakeholders of the value chain of technology transfer process in the Moroccan universities.

Legend : Figure 1

$\begin{array}{ll}\text { UTTU } & : \text { University Technology Transfer Unit } \\ \text { Inv/R } & : \text { Inventor/Researcher } \\ \text { EP } & : \text { Economic partners } \\ \text { Univ } & : \text { University } \\ P A & : \text { Public Authorities } \\ I P & : \text { Intellectual Property } \\ P T R & : \text { Prestation Technologique Réseau : A Technology development network finance } \\ & \\ \text { INNOV'ACT } & : \text { Pechanism aiming to support technological projects of industrial companies }\end{array}$

\subsection{Set of measures to be adopted to activate and professionalize the activities of the TTUO}

The establishment of a TTUO structure within the university is an important prerequisite for starting any TT process from the university to the business. The key performance indicators (patents, licenses and royalties) of the TT process indicate which institution is doing well in this activity.

The analysis of the performance of the most efficient institutions, or the practical benchmarking, has made it possible to map the factors that influence internal policies and procedures. These factors are [45]:

1. To recognize formally the mission of TT as a primary task of the university.

2. To mobilize qualified, sufficient and appropriate human resources in accordance with the volume of activities and technologies targeted;

3. To establish a culture within the university that supports and promotes TT activities;

4. To set up a professional TTUO with an entrepreneurial approach and a customer-friendly attitude 
(service-oriented TTUO);

5. To adopt a well-defined policy, rules and procedures;

6. To allocate an appropriate budget for legal patent protection (patent registration; patent portfolio management and protection);

7. To allocate an appropriate budget for Proof of Concept activities;

8. To start TTUO's activities as soon as possible so that the university can devote enough time to resource development and growth.

On the other hand, regarding the specificities of the Moroccan university context, the operationalization and development of TTUO's activities require the adoption of a set of measures (Package), which can be grouped as follows:

\section{A. Legal and regulatory measures at national level:}

Several studies and evaluations of previous experiences (Moroccan Incubation Network and University-Business Interface Program) have highlighted the crucial importance of giving these TTUOs financial and administrative autonomy. This independence can be achieved through the adoption of the legal framework for associations, or in the form of a private company. Indeed, these legal forms allow flexible and efficient management and offer important advantages such as:

- Simplification of administrative and financial procedures related to collaboration with companies, research exploitation activities and incubator management;

- Strengthening good governance;

- Encouraging researchers by facilitating access to the financial performance of completed projects.

- Effective involvement of the private sector in the decision-making body of TTUO.

\section{B. Coordination and governance measures}

These measures will ensure good governance while improving coordination between the various actors involved, namely:

- Ministerial departments and national public agencies: Their mission is to provide technical and financial support and to create the material and organizational conditions to facilitate the work of TTUOs. They are also responsible for evaluating and monitoring the activities carried out.

- Regional authorities: Their mission is to participate in the financing effort and in the provision of the land to establishes appropriate infrastructures. They must participate in the identification of regional priorities. In order to create an enabling regional innovation ecosystem, they can consider the decentralized social and economic network by creating a virtual space for cooperation to provide the global opportunities for regional actors [46].

- Research Institutes, laboratories and research centers: Their mission is to propose and implement projects, solutions and technologies.
- Industrial Companies: Their role is to participate, based on their experiences, in the identification of needs in order to better guide the efforts to promote research results and to work directly on research, development and innovation projects with laboratories and research teams. Also they can develop special clusters to promote $R \& D$ and to stimulate entrepreneurship in their specific sectors of activity (ICT Clusters in Poland as an Example [47]).

- Banks and financial and investment institutions: their involvement is necessary because TTUOs offer interesting investment opportunities since they are considered as sources of wealth creation.

\section{Technical support and financial support measures at national level:}

The need to develop programs and mechanisms for technical and financial support supervised by the competent public authorities in a contractual framework with universities to enable them to develop and improve their TTUO services.

\section{Measures to be taken by the university}

- Meanwhile, the establishment of a legal status that will guarantee the autonomy and effectiveness of TTUO, it is necessary to clarify the status of TTUO as a common service of the university presidency and integrate it into its organizational chart;

- Formally identify and clarify the missions and objectives of TTUOs;

- Provide TTUOs with sufficient resources;

- Recruitment via fixed-term contracts.

\section{CONCLUSION}

The awareness of Moroccan universities of the importance of the third mission, alongside the missions of training and research, has led to progressive development since 1998. Thus, policies and strategies were developed and adopted, mechanisms and structures copied or designed, and financial and human resources allocated. All this has been implemented and managed taking into account, to a certain degree, the specificities of the country as well as international standards. However, the results, or more precisely the rhythm of evolution, have not succeeded in exploiting the latent potential of Moroccan universities.

In this work, we were able to highlight and analyse the policies and programs, within Moroccan universities, related to TT activities. Also, a more appropriate value chain for the TT process was proposed, while detailing the missions and roles of TTOs in the upstream phases of the process. And finally, a set of measures to be adopted to activate and professionalize the activities of TTUOs was recommended. 
In the second part of this work, we are planning to complete it by proposing a complete reference framework for the implementation of the TTUO structure, which will contain the conditions for this implementation, its attributions and activities, its components and its organizational diagram.

However, the success of the Moroccan public university in this third mission remains highly dependent on the state of the regional and national innovation ecosystem in Morocco. Subsequent work will further clarify, in a more in-depth way, the characterization and modelling of this ecosystem "National System of Innovation in Morocco" as well as the identification of all the factors or groups of factors that interact in a complex way to form the National Innovation System in Morocco.

\section{APPENDIX}

Appendix 1: List of industrial clusters in Morocco.

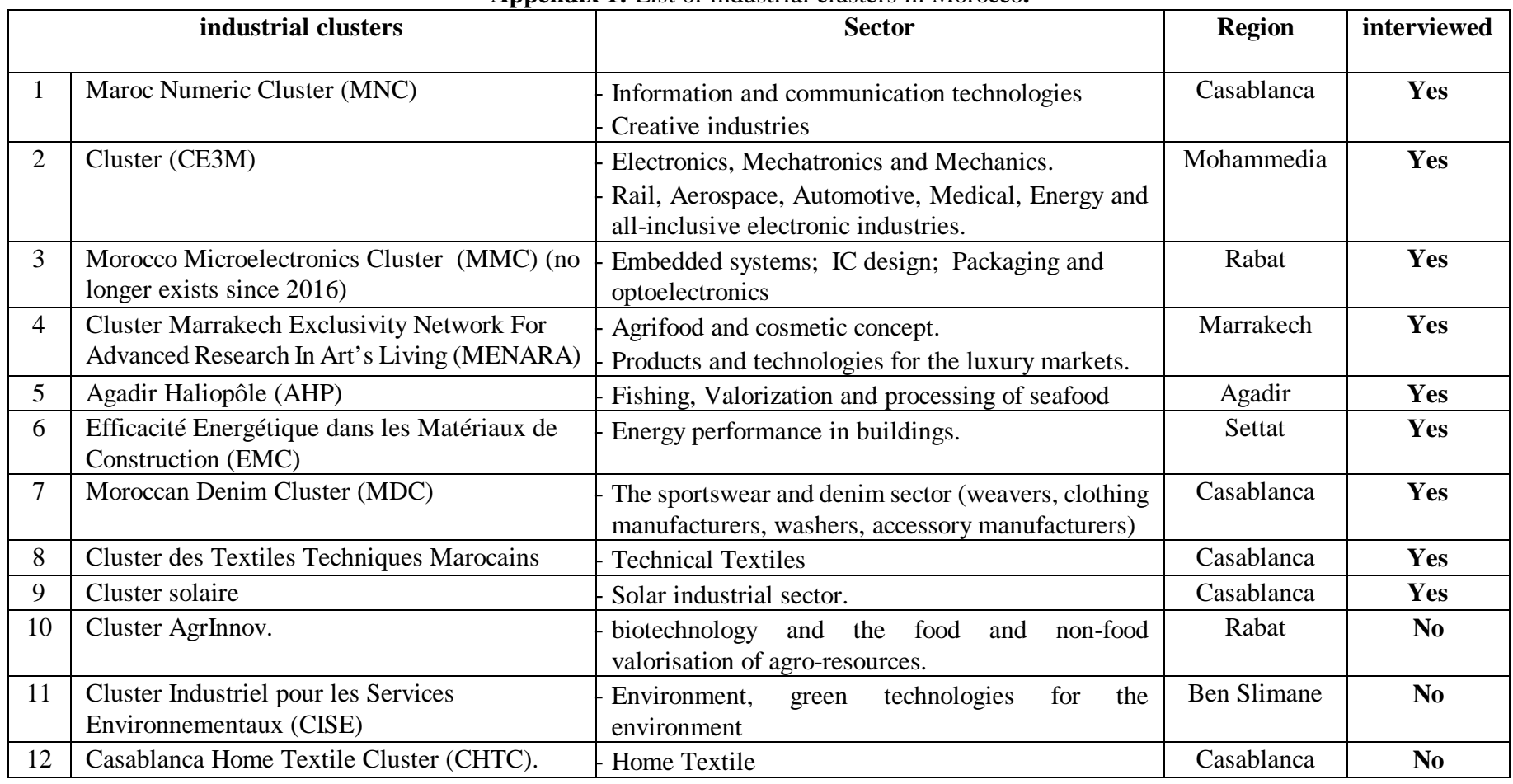

Appendix 2: List of public universities chosen on the basis of the existence of a TT structure and their achievements in terms of Patent's Filing.

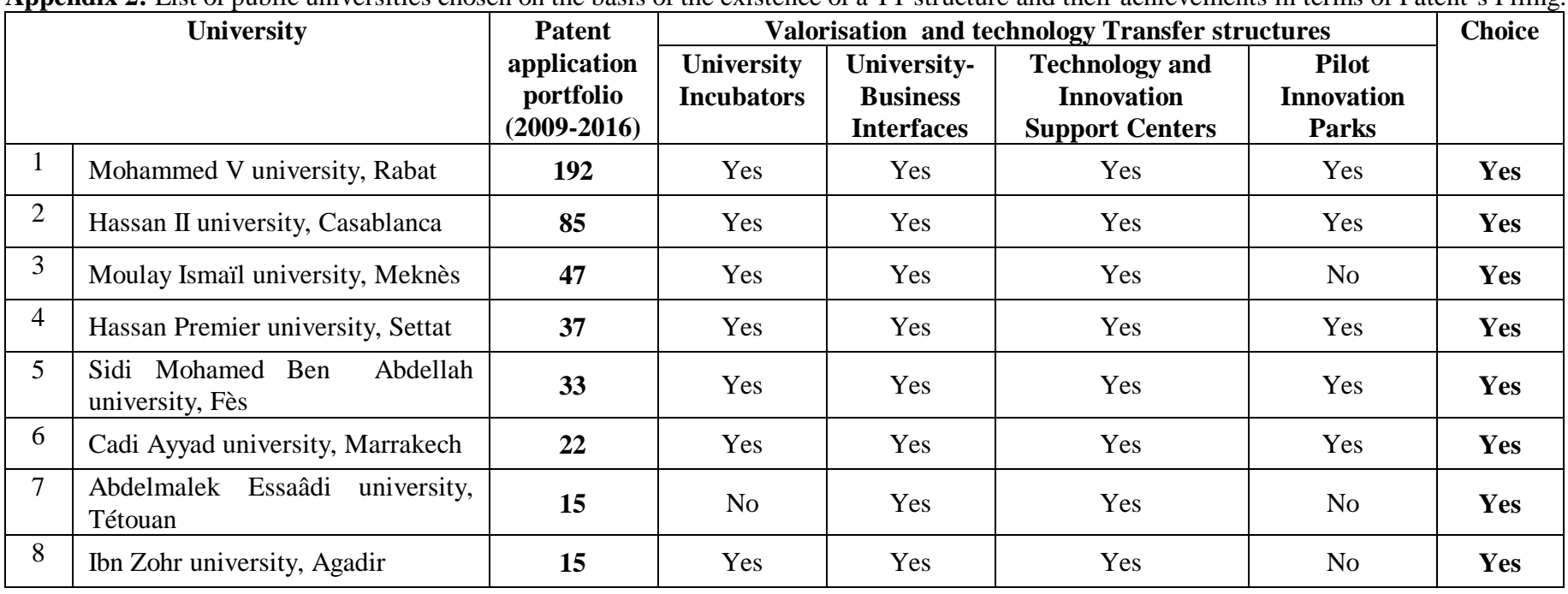




\begin{tabular}{|c|l|c|c|c|c|c|c|}
\hline 9 & Ibn Tofaïl university, Kénitra & $\mathbf{1 0}$ & Yes & Yes & Yes & No & No \\
\hline 10 & $\begin{array}{l}\text { Chouaïb Doukkali university, El } \\
\text { Jadida }\end{array}$ & $\mathbf{9}$ & Yes & Yes & Yes & No & No \\
\hline 11 & $\begin{array}{l}\text { Mohammed Premier université, } \\
\text { Oujda }\end{array}$ & $\mathbf{4}$ & Yes & Yes & Yes & No & No \\
\hline 12 & $\begin{array}{l}\text { Sultan Moulay Slimane, university } \\
\text { Beni-Mellal }\end{array}$ & -- & Yes & Yes & Yes & No & No \\
\hline
\end{tabular}

Appendix 3: List of University-Business Interfaces in the Moroccan Universities.

\begin{tabular}{|c|l|l|}
\hline \multicolumn{2}{|c|}{ University } & \multicolumn{1}{c|}{ Names of University-Business Interfaces } \\
\hline 1 & Mohammed V university, Rabat & Structure de Valorisation de la Recherche de l'UM5A \\
\hline 2 & Hassan II university, Casablanca & $\begin{array}{l}\text { - Appui et Partenariat avec l'Entreprise (APE) } \\
\text { - INUNEM / L'interface Université/Entreprise }\end{array}$ \\
\hline 3 & Moulay Ismaïl university, Meknès & $\begin{array}{l}\text { Cellule d'interface / Service des Relations Extérieures et de la Formation } \\
\text { Continue /Centre d'Incubation, de Formation et de Transfert Technologique }\end{array}$ \\
\hline 4 & Hassan Premier university, Settat & Interface UHP \\
\hline 5 & Sidi Mohamed Ben Abdellah university, Fès & Centre Universitaire Régional d'Interface \\
\hline 6 & Cadi Ayyad university, Marrakech & Interface université environnement Socio-économique \\
\hline 7 & Abdelmalek Essaâdi university, Tétouan & Service des relations extérieurs et de coopération / Structure d'Interface \\
\hline 8 & Ibn Zohr university, Agadir & Interface de l'Université IBN ZOHR \\
\hline 9 & Ibn Tofaïl university, Kénitra & $\begin{array}{l}\text { Service d'Interface Université Ibn Tofail (SIUIT) /Cellule d'Interface } \\
\text { Université - Entreprise }\end{array}$ \\
\hline 10 & Chouaïb Doukkali university, El Jadida & Centre d'Orientation, de Valorisation, d'Incubation et de Formation \\
\hline 11 & Mohammed Premier université, Oujda & $\begin{array}{l}\text { Centre Universitaire pour le Développement de la Région de l'Oriental - } \\
\text { CUDRO - }\end{array}$ \\
\hline 12 & Sultan Moulay Slimane, university Beni-Mellal & Cellule d'Interface /Interface Universitaire \\
\hline
\end{tabular}

Appendix 4: List of University Incubators whose officials were interviewed.

\begin{tabular}{|c|c|c|}
\hline & University or Institution & Names of University Incubators (17) \\
\hline 1 & Mohammed V university, Rabat & $\begin{array}{l}\text { Centre d'Innovation Technologique (CIT). } \\
\text { Centre Universitaire de l'Entrepreneuriat. }\end{array}$ \\
\hline 2 & Hassan II university, Casablanca & Incubateur de l'UH2C. \\
\hline 3 & Moulay Ismaïl university, Meknès & Incubateur Universitaire IBDA3 \\
\hline 4 & Hassan Premier university, Settat & Incubateur MaroBtikar \\
\hline 5 & Sidi Mohamed Ben Abdellah university, Fès & Incubateur de la Cité d'Innovation de Fès \\
\hline 6 & Cadi Ayyad university, Marrakech & Incubateur Universitaire de Marrakech (INMA) \\
\hline 7 & Abdelmalek Essaâdi university, Tétouan & Incubateur Universitaire \\
\hline 8 & Ibn Zohr university, Agadir & Incubateur Régional Inter-universitaire du Sud (IRIS) \\
\hline 9 & Ibn Tofaïl university, Kénitra & $\begin{array}{l}\text { Centre Universitaire d'Analyses, d'Expertise, de Transfert de } \\
\text { Technologies et d'Incubation d'Entreprises (CUAE2Ti) }\end{array}$ \\
\hline 10 & Chouaïb Doukkali university, El Jadida & Centre Universitaire Doukkala Incubation (CUDI) \\
\hline 11 & Mohammed Premier université, Oujda & Incubateur Dynamique Est; \\
\hline 12 & Sultan Moulay Slimane, university Beni-Mellal & Centre Universitaire d'Incubation de Tadla-Azilal (CUITA) \\
\hline 13 & Al Akhawayn university, Ifrane. & Al Akhawayn Incubator \\
\hline 14 & Internationale university of Rabat. & Incubateur de l'UIR. \\
\hline 15 & Ecole Nationale Supérieure Des Mines, Rabat & $\begin{array}{l}\text { Centre d'Incubation et d'Accueil des Entreprises Innovantes } \\
\text { (CIAEI) }\end{array}$ \\
\hline 16 & $\begin{array}{lcccc}\text { Institut } & \text { National } & \text { Des } & \text { Postes } & \text { Et } \\
\text { Télécommunications } & & & \\
\end{array}$ & Incubateur RESIN \\
\hline 17 & $\begin{array}{l}\text { Centre National Pour La Recherche Scientifique Et } \\
\text { Technique CNRST }\end{array}$ & Pépinière Maroc Incubation du CNRST \\
\hline 18 & Technopark de Casablanca & Incubateur du Technopark \\
\hline
\end{tabular}


Appendix 5: List of innovation cities pilots whose officials were interviewed.

\begin{tabular}{|c|l|l|l|l|}
\hline & \multicolumn{1}{|c|}{ University } & \multicolumn{1}{|c|}{ Name of the innovation Park } & Start Date & City/Region \\
\hline 1 & Mohammed V, Rabat & CIR : Cité de l'Innovation de Rabat & 2016 & Rabat \\
\hline 2 & Hassan Premier, Settat & CIS : Cité de l'Innovation de Settat & 2016 & Settat \\
\hline 3 & Sidi Mohamed Ben Abdellah, Fès & CIF : Cité de l'Innovation de Fès & 2013 & Fès \\
\hline 4 & Cadi Ayyad, Marrakech & CIM : Cité de l'Innovation de Marrakech & 2011 & Marrakech \\
\hline
\end{tabular}

\section{REFERENCES}

1. Ambos, T. C, Makela, K., Birkinshaw, J., and D'Este, P., 2008. When does university research get commercialized? Creating ambidexterity in research institutions. Journal of Management Studies, 45(8), 1424-14.

https://doi.org/10.1111/j.1467-6486.2008.00804.x

2. Law $\mathrm{n}^{\circ} 01-00$. Organization of higher education in Morocco (2000). B. O. No. 4800 of 1 June 2000. Dahir $\mathrm{n}^{\circ}$ 1-00-199 of 15 Safar 1421 (19 May 2000) promulgating Law $\mathrm{n}^{\circ} 01-00$ on the organization of higher education. Morocco. Available from: https://www.enssup.gov.ma/sites/default/files/ETABLIS SEMENT-SUP/Dahir_n-1-00 199_du19mai2000.pdf

3. Etzkowitz, H., 2003. Research groups as 'quasi-firms': The invention of the entrepreneurial university. Research Policy, 32(1), 109-121. https://doi.org/10.1016/S0048-7333(02)00009-4

4. Rasmussen, E., Moen, O. and Gulbrandsen M., 2006. Initiatives to promote commercialization of university knowledge. Technovation, 26(4), 518-533. https://doi.org/10.1016/j.technovation.2004.11.005

5. Wright, M., Clarysse, B., Lockett, A. and Knockaert, M., 2008. Mid-range universities' linkages with industry: Knowledge types and role of intermediaries. Research Policy, 37(8), 1205-1223. https://doi.org/10.1016/j.respol.2008.04.021

6. Van Looy, B., Landoni, P., Callaert, J., Van Pottelsberghe, B., Sapsalis, E. and Debackere, K., 2011. Entrepreneurial effectiveness of European universities: An empirical assessment of antecedents and trade-offs. Research policy, 40 (4), 553-564. https://doi.org/10.1016/j.respol.2011.02.001

7. Siegel, D. S., Veugelers, R. and Wright M., 2007. Technology transfer offices and commercialization of university intellectual property: Performance and policy implications. Oxford Review of Economic Policy, 23(4), 640-660.

https://doi.org/10.1093/oxrep/grm036

8. Tushman, M. L. and O'Reilly, C. A., 1996. Ambidextrous organizations: Managing evolutionary and revolutionary change. California Management Review, 38(4), 8-30. https://doi.org/10.2307/41165852

9. Siegel, D. S., Westhead, P. and Wright, M., 2003b. Assessing the impact of university science parks on research productivity: Exploratory firm-level evidence from the United Kingdom. International Journal of industrial Organization, 21(9), 1357-1369. https://doi.org/10.1016/S0167-7187(03)00086-9

10. Coupe, T., 2003. "Science is golden: Academic R\&D and university patents. The Journal of Technology Transfer, 28(1),31-46. https://doi.org/10.1023/A:1021626702728

11. Link, A. N. and Scott, J. T., 2005. Opening the ivory tower's door: An analysis of the determinants of the formation of US university spin-off companies. Research Policy, 34(1), 1106-1112.

12. Lockett, A. and Wright, M., 2005. Resources, capabilities, risk capital and the creation of university spin-out companies. Research Policy, 34(7), 1043-105.

13. Lockett, A., Wright, M. and Franklin, S., 2003). Technology transfer and universities' spin-out strategies. Small Business Economics, 20(2), 185-200. https://doi.org/10.1023/A:1022220216972

14. Debackere, K. and Veugelers, R., 2005. The role of academic technology transfer organizations in improving industry science links. Research Policy, 34(3), 321-342.

15. Siegel, D. S., Waldman, D. and Link, A., 2003 a. Assessing the impact of organizational practices on the relative productivity of university technology transfer offices: An exploratory study. Research policy, 32(1), 27-48.

16. Vohora, A., Wright, M., and Lockett, A., 2004. Critical junctures in the development of university high-tech spinout companies. Research Policy, 55(1), 147-17.

17. Macho-Stadler, I., Perez-Castnllo, D. and Veugelers, R., 2007. Licensing of university inventions: The role of a technology transfer office. International Journal of Industrial Organization, 25(3), 483-510. https://doi.org/10.1016/j.ijindorg.2006.06.001

18. Hoppe, H. C. and Ozdenoren, E., 2005. Intermediation in innovation. International Journal of Industrial Organization, 23(5-6), 483-50

19. Markman, G. D., Gianiodis, P. T., Phan, P. H. and Balkin, D. B., 2005. Innovation speed: Transferring university technology to market. Research Policy, 34(1), 1058-1075.

20. Bercovitz, J., Feldman, M., Feller, I., and Burton, R., 2001. "Organizational structure as a determinant of academic patent and licensing behavior: An 
exploratory study of Duke, Johns Hopkins, and Pennsylvania State universities. The Journal of Technology Transfer, 26(1), 21-35.

https://doi.org/10.1023/A:1007828026904

21. MNEPTHESR (Ministry of National Education, Professional Training, Higher Education and Scientific Research), 2017a. MNEPTHESR 2016 Activity Report, Morocco.

22. MNEPTHESR (Ministry of National Education, Professional Training, Higher Education and Scientific Research), 2017b. University-Enterprise Partnership: National Program of University-Enterprise Interfaces. MNEPTHESR, Morocco. [Online] Available at:

http://www.enssup.gov.ma/fr/Page/339-partenariat-univ ersité-entreprise (2017)

23. CNRST (The Moroccan National Centre for Scientific and Technical Research), 2017a. Morocco Incubation \& Spin-off Network (RMIE). Morocco. [online]. Available on: http://www.rmie.ma/

24. CNRST (The Moroccan National Centre for Scientific and Technical Research), 2017b. Annual report 2011, Morocco. [online]. Available on: http://www.cnrst.ma/img/annee2013/rapport_annuel_2 011.pdf

25. CNRST (The Moroccan National Centre for Scientific and Technical Research), 2017c. Annual report 2015, Morocco.

26. OMPIC (The Moroccan Office of Industrial and Commercial Property), 2017a. Annual Report 2016. Morocco.

27. MIITDE (Ministry of Industry, Investment, Trade and the Digital Economy), 2017a. Annual report 2015, Morocco.

28. MHESRET (Ministry of Higher Education, Scientific Research and Executive Training), 2013. Annual report 2013. Morocco.

29. Elyoussoufi Attou, O. and Arouch, M., 2016). Current situation of the national system of the technological innovation in Morocco. International Journal of Innovation and Scientific Research, vol. 20, no. 1, pp. 83-89, January 2016.

30. MNEPTHESR (Ministry of National Education, Professional Training, Higher Education and Scientific Research), 2017c. University-Enterprise Partnership: Cities of Innovation. Morocco. [online]. Available on: http://www.enssup.gov.ma/fr/Page/339-partenariat-univ ersité-entreprise (2017)

31. OMPIC (The Moroccan Office of Industrial and Commercial Property), 2017b. TISC: Technology and Innovation Support Centers. Morocco. [online]. Available on: http://www.tisc.ma/reseau_tisc/page-11-2.html

32. MNEPTHESR (Ministry of National Education, Professional Training, Higher Education and Scientific Research), 2017d. University-Enterprise Partnership: The Clusters. Morocco. [online]. Available on:
http://www.enssup.gov.ma/fr/Page/339-partenariat-univ ersité-entreprise (2017)

33. MIITDE (Ministry of Industry, Investment, Trade and the Digital Economy), 2017b. Industrial Technical Centers. Morocco. [online]. Available on: http://www.mcinet.gov.ma/fr/content/centres-technique s-industriels.

34. CNRST (Moroccan National Centre for Scientific and Technical Research), 2017d. Funding of research projects: research and technological development in priority areas "PPR". Morocco. [online]. Available on: http://www.cnrst.ma/index.php/fr/financement-de-la-re cherche/programmes-nationaux/financement-des-projet s-de-recherche.

35. MNEPTHESR (Ministry of National Education, Professional Training, Higher Education and Scientific Research), 2017e. Funding Programs for Research Projects: INNOV'ACT Program. Morocco. [online]. Available on: http://www.enssup.gov.ma/fr/Page/337-programmes-definancements-des-projets-de-recherche (2017).

36. MHESRET (Ministry of Higher Education, Scientific Research and Executive Training), 2009a. Report of the national meeting of interfaces in Meknes in 2004, Morocco.

37. MHESRET (Ministry of Higher Education, Scientific Research and Executive Training), 2009b. Report of the national interface meeting in Tetouan in 2009. Morocco.

38. CNRST (The Moroccan National Centre for Scientific and Technical Research), 2006. Evaluation Report of the Morocco Incubation and Spin-off Network RMIE- 2006. Morocco

39. MHESRET (Ministry of Higher Education, Scientific Research and Executive Training), 2007. Progress report on the Tempus SILA program. Morocco.

40. MHESRET (Ministry of Higher Education, Scientific Research and Executive Training), 2014a. Final Report of the Institutional Twinning Project Morocco \& European Union: "Support to the National Research System in Morocco for Integration into the European Research Area" (2011-2013). Morocco.

41. MHESRET (Ministry of Higher Education, Scientific Research and Executive Training), 2014b. Proceedings of the National Conference of Scientific Research and Innovation in Morocco. Morocco.

42. Siegel, D.S., Waldman, D. A., Atwater, L. and Link, A. N., 2004. Toward a model of the effective transfer of scientific knowledge from academicians to practitioners: qualitative evidence from the commercialization of university technologies. Journal of Engineering and Technology Management, 21(1-2), 115-142.

43. Thursby, J.G., Jensen, R. A. and Thursby, M. C., 2001. Objectives, characteristics and outcomes of university licensing: a survey of major U.S. universities. Journal of Technology Transfer, 26(1-2), 59-70. 
https://doi.org/10.1023/A:1007884111883

44. SATT Network (Technology Acceleration Transfer Companie). 2017. What are SATTs? France. [online]. Available on:

https://www.satt.fr/societe-acceleration-transfert-techno logies.

45. Tornatzky, L. G. and Waugaman, P. G., 1999. Academic Culture and Technology Transfer: Some Change Interventions. R\&D Enterprise Asia Pacific, vol. 2, no. 2-3.

https://doi.org/10.5172/impp.1999.2.2-3.29

46. Nekrasenko, L., Kalinichenko, A., Brzozowska, A., Lazurenko, B., 2019. Decentralized Social and Economic Network as an Alternative Economic Relations Development In Society. International Journal of Advanced Trends in Computer Science and Engineering, Volume 8, No.1.1. 308-313.

https://doi.org/10.30534/ijatcse/2019/5481.12019

47. Tomasz Żminda, 2019. Entrepreneurship in the Area of Activity of Key ICT Clusters in Poland. International Journal of Advanced Trends in Computer Science and Engineering, Volume 8, No.1.1. 63-66. https://doi.org/10.30534/ijatcse/2019/0481.12019 